\title{
Current and desired organizational culture of the financial system of the province of Huancayo,
} Peru

\author{
Nivardo Alonzo Santillán-Zapata ${ }^{a^{*}}$, Pedro Bernabe Venegas-Rodriguez ${ }^{a}$, Jovany Pompilio Espinoza-Yan- \\ galia $^{\mathrm{a}}$, Katrin Evelyn Pahuacho-Rojas ${ }^{\mathrm{a}}$ and Giuliana Ysela Siuce-Simeon ${ }^{\mathrm{a}}$
}

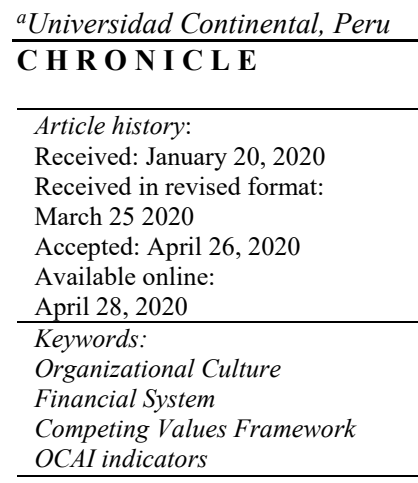

\author{
A B S T R A C T \\ The objective of this investigation was to identify the current organizational culture of \\ the financial system of the province of Huancayo and the culture that they wanted, to \\ serve as a complement to the traditional indicators of the sector. The Organizational Cul- \\ ture Assessment Instrument (OCAI) was practiced on 412 workers from 16 financial in- \\ stitutions. It is a quantitative, non-experimental and descriptive study.
}

\section{Introduction}

According to central banks, the most common indicators to evaluate a financial system are (a) profitability, (b) liquidity, (c) solvency, etc. According to these indicators, Peru's financial system is stable and growing, showing itself "in a comfortable standard and... at its average levels of the last five-year period" (Banco Central de Reservas del Perú [BCRP], 2019). Other indicators that are also considered come to be: (a) credit growth, (b) over-indebtedness, (c) non-performing loans, (e) interest rates, and (f) macroeconomic scenarios, concerning these. The Peruvian financial sector presented a stronghold in 2019 due to: (a) macroeconomic stability, (b) fiscal discipline, and (c) a regulatory framework (BCR, 2019). This research carries out an additional evaluation that goes beyond conventional economic and financial indicators, as it measures and analyzes Organizational Culture (OC), identifying what people who work in the financial system feel, believe and value, considering that performance and efficacy are, sooner or later, affected by OC (Cameron \& Quinn, 2011). Therefore, the management must consider the influence and impact of the culture, giving relevance to its measurement, diagnosis, and analysis, as well as traditional indicators.

\section{Literary review}

\subsection{Organizational culture (OC)}

Problems and negative outcomes within corporations have several causes, this section addresses those that are influenced by OC. For Schein (1983) OC is the improvement of learning through patterns that follow and value a group to solve problems and that are conceived as the correct way of thinking, feeling and acting in front of them. Nevertheless, it is not only a style of solving problems but it is also a generator of these, for example, the intention to resign or the rotation of staff due to job 
dissatisfaction may also be influenced by OC (Macintosh \& Doherty, 2010; Fuchs \& Torre, 2012), in the same way, influencing readiness and organizational learning, making them fast or slow, as well as contributing to the management and adaptation of changes (Felipe et al., 2017; Gómez, 2017; Valle et al., 2017), in terms of effective communication, makes the transfer of knowledge more successful and efficient (Hartnell et al., 2011; Nguyen \& Mohamed, 2011; Máynez-Guaderrama et al., 2012). Other implications of OC are evident in management styles, resistance to the implementation of a quality management system, in the promotion of innovation, the assessment and belief in social responsibility (Guillén \& Aduna, 2008; Naranjo-Valencia et al., 2011; Prajogo \& McDermont, 2011; Hogan \& Coote, 2014; Barahona \& Rodríguez, 2017; Moonen, 2017; Gutiérrez et al., 2017). Also striking in corporate sustainability, the organizational climate, structure, strategies, among others (Linnenluecke \& Griffiths, 2010; Zheng et al., 2010; Schneider et al., 2013).

\subsection{Competing Values Framework (CVF)}

According to the CVF model by Cameron and Quinn (2011), OC can be evaluated through four archetypes: (a) Clan, in which sharing, family environments, mentoring, tradition, concern for the person, teamwork, participation, and consensus are valued; (b) Adhocracy, is characterized by dynamism, entrepreneurship, and creativity, with emphasis on facing risks, challenges and changes; (c) Market, they are governed by results, competition, demand, market growth and ambitious goals; and (d) Hierarchy, in which formality, rules, stability, and policies prevail. In Fig. 1 it can be seen that the four archetypes coexist and constitute the OC.

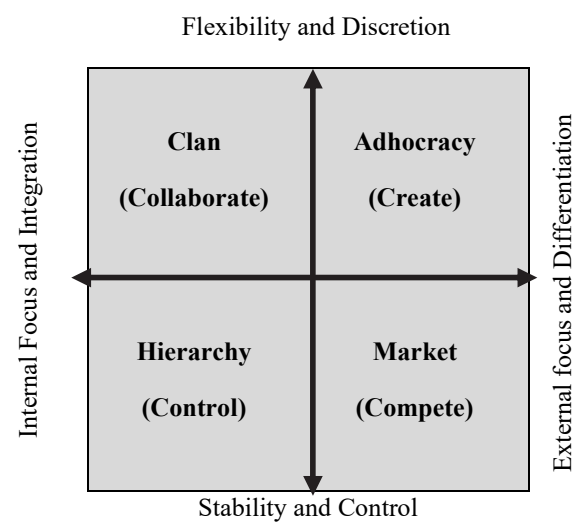

Fig.1. The Competing Values Framework (Cameron \& Quinn, 2011)

\subsection{Current culture and preferred future culture}

The CVF through the OCAI allows us to measure where our organization is through the current culture and where we want to be with the desired culture. Both should be compared because there are possible large differences that would generate many problems in the management of organizations. Therefore, there is an OC in place today and another one that would be desired in the future, highlighting the aspirational values to which employees want to adhere. Fig, 2 shows how the CVF model visually represents both cultures to be analyzed.

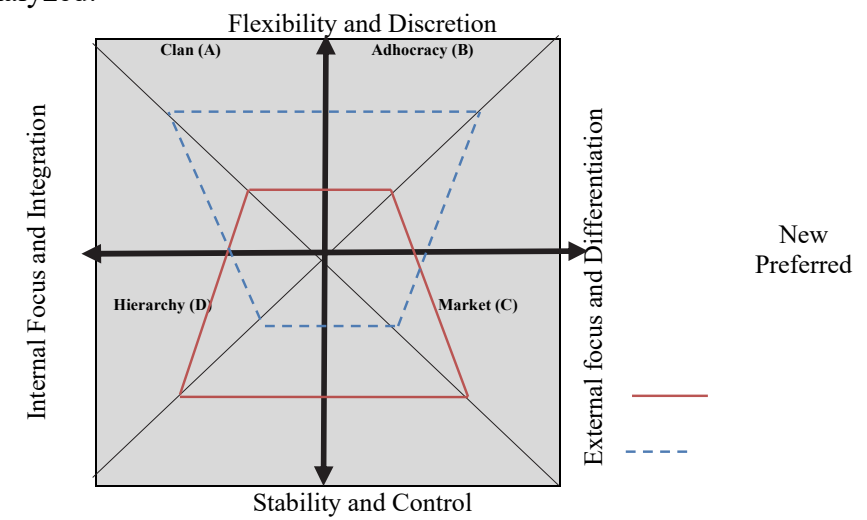

Fig. 2. Current culture and preferred future culture (Cameron \& Quinn, 2011)

\subsection{Organizational Leadership}

In Fig. 3 thee can identify: (a) orientation, (b) type of leader, (c) value drivers, and (d) theories of effectiveness for each type of culture, this provides an orientation and a starting point to managers to lead with the change or alignment to the type of culture that the organization believes most convenient. 
Flexibility and Discretion

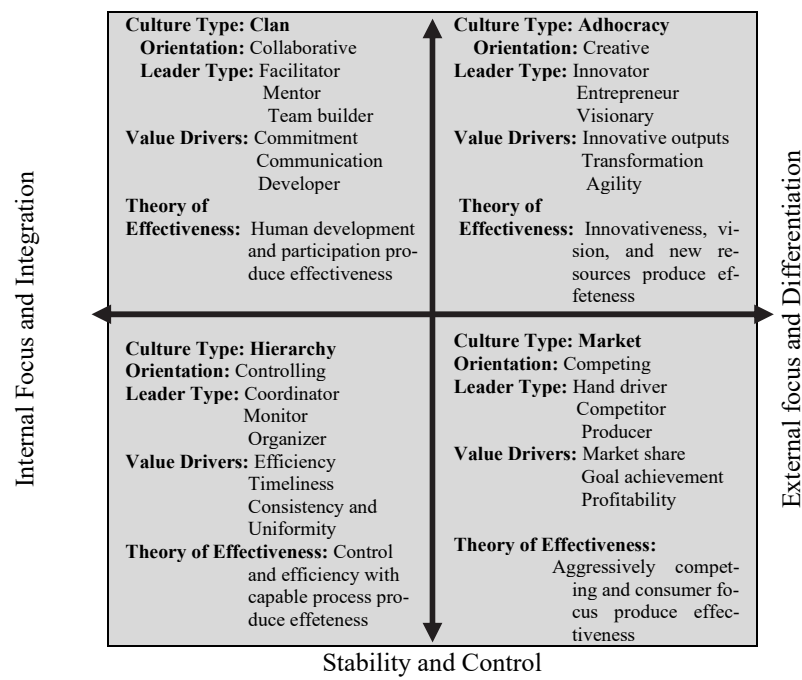

Fig. 3. The Competing Values of Leadership, Effectiveness, and Organizational Theory (Cameron \& Quinn, 2011)

\subsection{Human Resource Management Roles}

Fig. 4 shows: (a) roles, (b) means, (c) purposes, and (d) competencies that must be taken into account in each type of culture to be more successful in managing human resources and lessen possible negative impacts caused by OC (Cameron \& Quinn, 2011).

Flexibility and Discretion

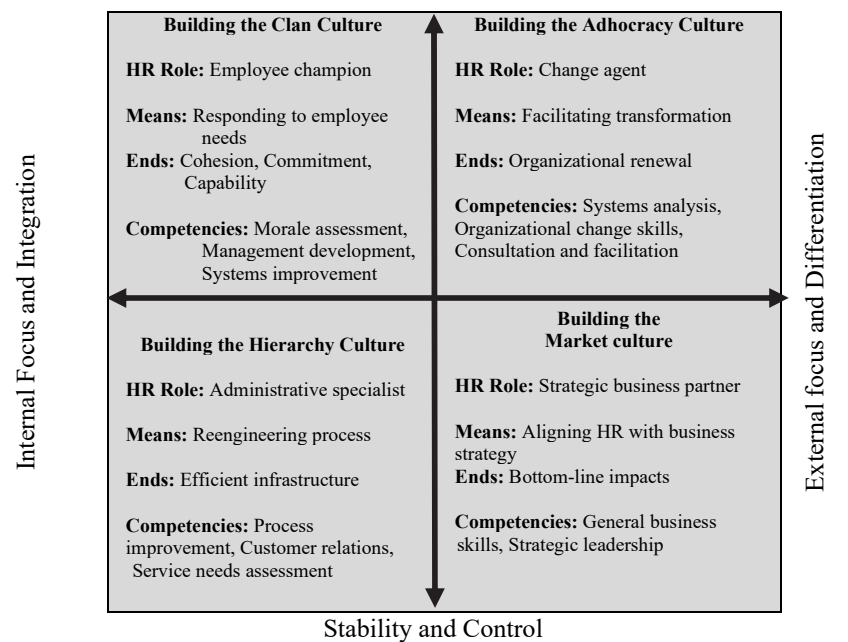

Fig. 4. The Competing Values of Human Resource Management (Cameron \& Quinn, 2011)

\section{Method}

The research has a quantitative, non-experimental, cross-sectional and descriptive level approach (Hernández et al., 2014). To diagnose $\mathrm{OC}$ in the financial system, 412 workers from 16 financial entities participated, 174 from the banking system and 238 from the non-banking system (financial and microfinance), 190 women and 222 men, with ages between 20 and 60, with experience from 1 to more than 15 years, who worked in positions such as (a) cashier/counter, (b) product advisor, and (c) support. Its application was made in the province of Huancayo in the department of Junín - Peru in 2018. The objective of the study was to identify the current organizational culture of the financial sector and the one they wanted in the future.

\subsection{Instrumentation}

The instrument used was the Organizational Culture Assessment Instrument (OCAI) by Cameron and Quinn from the Competing Values Framework (CVF) model of their book Diagnosing and Changing Organizational Culture, which identifies the current culture of the organization, as well as what the workers think it should be, in other words, the culture they want. The OCAI is made up of six dimensions: (a) Key characteristics, (b) Leadership in my organization, (c) Management style, (d) Union in the organization, (e) Strategic emphasis, and (f) Criterion for success, which contain the archetypes of the four 
cultures represented by a letter: (A) Clan, (B) Adhocratic, (C) Market, and (D) Hierarchical, which in total comprise 24 statements to qualify. The results for each culture are obtained from the average of the scores for each culture: (A), (B), (C), and (D) (Cameron \& Quinn, 2011). The instrument allows first measuring the current culture of the organization, then the desired one.

\subsection{Reliability and validity}

The Cronbach's alpha coefficient was calculated for each culture archetype representing the instrument, obtaining the following values: (a) Clan, .715; (b) Adhocratic, .712; (c) Market, .718; and (d) Hierarchical, .726, therefore evidencing high reliability. The OCAI was validated in the book Diagnosing and Changing Organizational Culture in a study of 334 institutions where 3,406 respondents participated (Cameron \& Quinn, 2011), also, Abbasi et al. (2013) carried out the construct validity through the Confirmatory Factor Analysis method, and multiple studies support the validity of the OCAI (Yu \& Wu, 2009).

\section{Results}

The results were analyzed on the current $\mathrm{OC}$ and the one that workers in the financial sector desire for the future. These can be considered as a starting point for managers related to this sector so that they reinforce and complement strategies to maintain or improve traditional indicators. To determine the perception of the current and desired OC, a descriptive analysis was carried out concerning the average of each culture to discern the level of intensity independently.

\subsection{OC of Financial System}

Table 1 shows the individual average of the four cultures, as well as for the current and desired OC of the Financial System, with which Fig. 5 is developed, from the CVF model, and the coexistence of the four can be seen. The most predominant are Market with 28.29 for the current one and Adhocracy with 27.77 for the desired one. The least predominant culture is Hierarchy with 21.27 for the current and 22.47 for the desired.

Table 1

Average Values for each Culture - Financial System

\begin{tabular}{|c|c|c|c|}
\hline \multirow[b]{2}{*}{ Culture } & \multicolumn{2}{|c|}{ Average } & \multirow[b]{2}{*}{ Deviation } \\
\hline & Now & Preferred & \\
\hline (A) Clan & 26.52 & 26.95 & 0.43 \\
\hline (B) Adhocracy & 23.92 & 27.77 & 3.85 \\
\hline (C) Market & 28.29 & 22.80 & -5.49 \\
\hline (D) Hierarchy & 21.27 & 22.47 & 1.20 \\
\hline
\end{tabular}

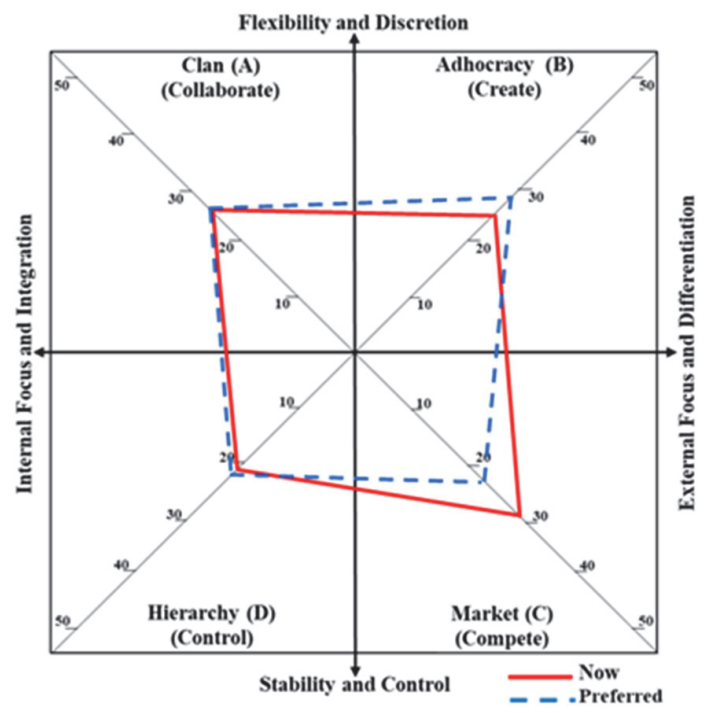

Fig. 5. Current and Desired Culture of the Financial System

\subsection{OC of Banking and Non-Banking system}

The individual average of each culture, as well as for the current and desired of the Banking System is presented in Table 2. Fig. 6 presents the coexistence of the four cultures, the most predominant being Clan with 30.45 for the current culture and Adhocracy with 27.54 for the desired culture. Also, the least predominant is Hierarchy with 20.21 for the current and 20.05 for the desired. 
Table 2

Average Values for each Culture - Banking System

\begin{tabular}{|c|c|c|c|}
\hline \multirow[b]{2}{*}{ Culture } & \multicolumn{2}{|c|}{ Average } & \multirow[b]{2}{*}{ Deviation } \\
\hline & Now & Preferred & \\
\hline (A) Clan & 30.45 & 26.73 & -3.71 \\
\hline (B) Adhocracy & 24.08 & 27.54 & 3.46 \\
\hline (C) Market & 25.26 & 25.68 & 0.42 \\
\hline (D) Hierarchy & 20.21 & 20.05 & -0.16 \\
\hline
\end{tabular}

Table 3 shows the average of the four cultures, both current and desired of the Non-Banking System; and Fig. 7 presents the coexistence between them, in which the most predominant are Market with 30.5 for the current one and Adhocracy with 27.94 for the desired one while the least predominant are Hierarchy with 22.05 for the current and Market with 20.69 for the desired.

Table 3

Average Values for each Culture - Non-Banking System

\begin{tabular}{|c|c|c|c|}
\hline \multirow[b]{2}{*}{ Culture } & \multicolumn{2}{|c|}{ Average } & \multirow[b]{2}{*}{ Deviation } \\
\hline & Now & Preferred & \\
\hline (A) Clan & 23.65 & 27.12 & 3.47 \\
\hline (B) Adhocracy & 23.80 & 27.94 & 4.14 \\
\hline (C) Market & 30.50 & 20.69 & -9.81 \\
\hline (D) Hierarchy & 22.05 & 24.24 & 2.20 \\
\hline
\end{tabular}

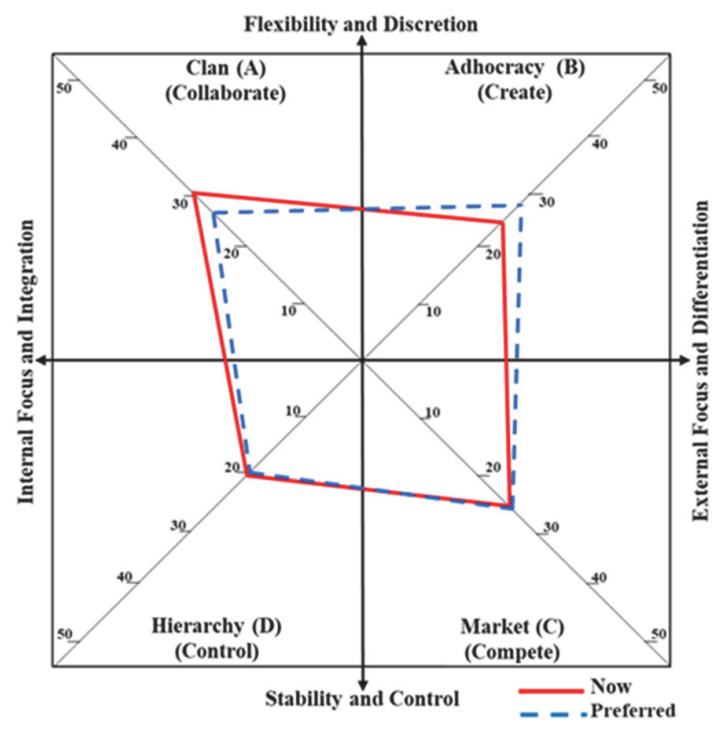

Fig. 6. Current and Desired Culture of the Banking System

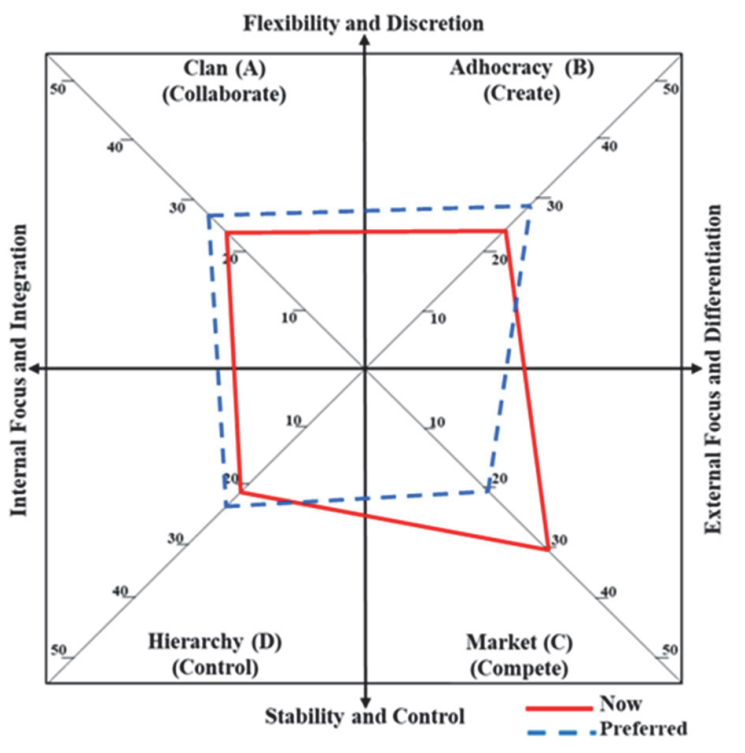

Fig. 7. Current and Desired Culture of the Non-Banking System

\subsection{OC according to Gender}

Table 4 and Fig. 8 presents the average of the current and desired culture according to the Female Gender, resulting in Market with 28.47 for the current culture and Adhocracy with 26.7 for the desired culture. The least predominant is Hierarchy with 20.86 for the current and 23.16 for the desired.

Table 4

Average Values for each Culture - Female Gender

\begin{tabular}{lccc} 
& & \multicolumn{3}{c}{ Average } & Preferred \\
\cline { 2 - 4 } & Culture & Now & 25.90 \\
(A) Clan & 26.75 & 26.70 & -0.85 \\
(B) Adhocracy & 23.91 & 24.24 & 2.79 \\
(C) Market & 28.47 & 23.16 & -4.24 \\
(D) Hierarchy & 20.86 & 2.30 \\
\hline
\end{tabular}

Finally, Table 5 and Fig. 9 show the average of the current and desired culture according to the Male Gender, in which the Market culture predominates with 28.13 for the current one and Adhocracy with 28.68 for the desired one. The least predominant are Hierarchy with 21.62 for the current and Market with 21.58 for the desired. 
Table 5

Average Values for each Culture - Male Gender

\begin{tabular}{|c|c|c|c|}
\hline \multirow[b]{2}{*}{ Culture } & \multicolumn{2}{|c|}{ Average } & \multirow[b]{2}{*}{ Deviation } \\
\hline & Now & Preferred & \\
\hline (A) Clan & 26.32 & 27.86 & 1.53 \\
\hline (B) Adhocracy & 23.92 & 28.68 & 4.76 \\
\hline (C) Market & 28.13 & 21.58 & -6.55 \\
\hline (D) Hierarchy & 21.62 & 21.88 & 0.26 \\
\hline
\end{tabular}

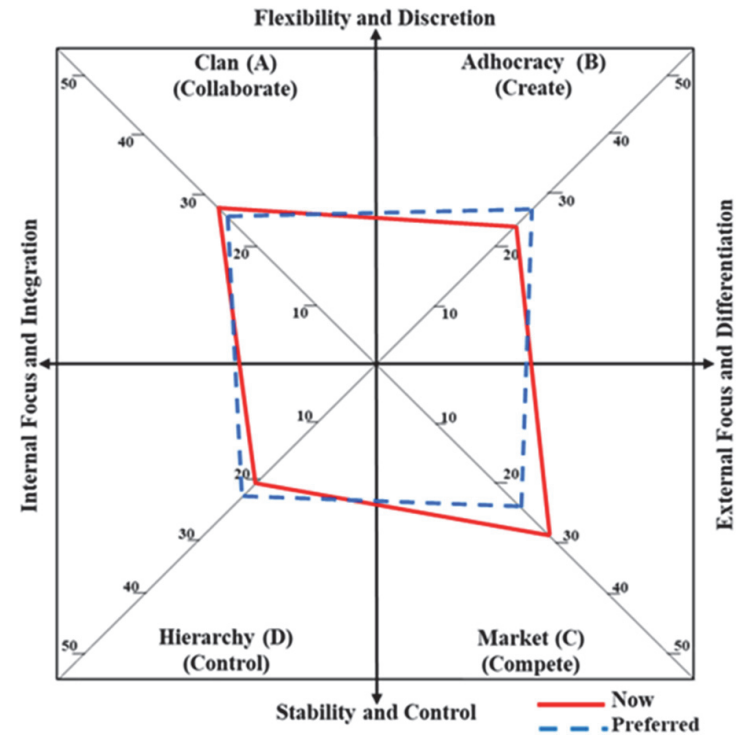

Fig. 8. Current and Desired Culture - Female Gender

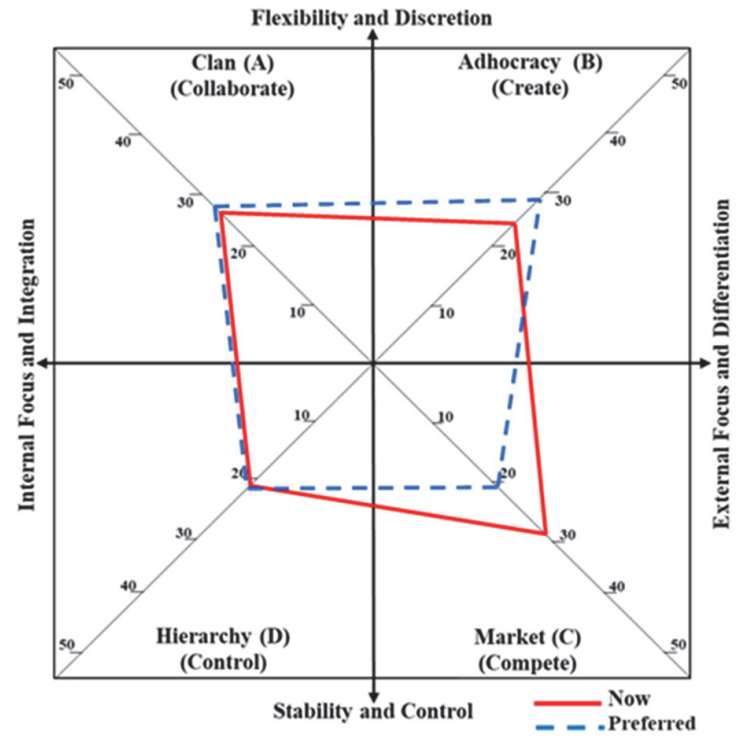

Fig. 9. Current and Desired Culture - Male Gender

\section{Discussion}

According to Cameron and Quinn (2011), the Market culture is the most predominant in the Financial System and the least predominant is the Adhocracy. According to the results of this research, the Market culture is also the most prevalent in the: (a) Financial System, (b) Non-Banking System, and (c) female and male gender, this means that the orientation on results prevails over the competition, demand, market growth, and ambitious goals. However, if the results are compared between the current and desired culture, we can see that in all cases they value more Adhocracy with characteristics of entrepreneurship, dynamism, creativity, with an emphasis on facing risks, challenges and changes; and a significant reduction in Market is fancied. In the Banking System, the current predominant culture is Clan, in which sharing, family environments, mentoring, teamwork, participation, and consensus are valued, wishing in the future a reduction of this one and an increase of Adhocracy. The current culture of less predominance, in general, is Hierarchy, in which formality, rules, stability, and policies prevail; and when it is contrasted with the desired culture, we evidence that a non-significant increase is expected, essentially keeping it as it is. The rendering of the results of the Non-Banking System and the Male Gender show the desire to reduce the Market culture considerably.

The current OC of the Banking System concerning the non-Banking is more oriented towards the Clan culture and less on Market, the other two cultures maintain similarity. In both systems, they want to increase the Adhocracy culture, reduce Clan in Banking and Market in non-Banking.

In both genders, the current perception is similar in the four cultures, for the desired scenario the predominant culture is Adhocracy, and they demand an increase in it, although with greater intensity in the male gender, making it clear that they want to reduce the Market culture.

It should be considered that in all organizations the suggested OC is proposed through its mission, vision and values, therefore managers are recommended to identify, compare and analyze OC from three perspectives: (a) current, ( b) the desired one, and (c) the one suggested by the same organization.

\section{Conclusion}

The results of the investigation have determined that the four types of CO coexist and the most dominant was Market, only in the Banking System dis Clan dominate. The most desired in all cases was Adhocracy. Therefore, it is recommended to manage alignment and change based on the CVF model. For example, to increase the Adhocracy culture, the leader of the organization should be oriented and more focused on being innovative, entrepreneurial, visionary, and creative. To build this culture, the 
role of human resources management must be an agent of change that facilitates organizational transformation and renewal. The fundamental competencies are systematic analysis, organizational change, agility in consultation and facilitation. To reduce the Market culture, the leader must focus on aggressive competitiveness with less priority, on only producing and achieving goals, moreover human resource management should not only be considered as a strategic commercial partner. In the case of the Banking System, it is possible to consider reducing the Clan culture through leadership with less priority on collaborative orientation and facilitation, to focus on increasing the characteristics of an Adhocracy culture.

Managers must know what their collaborators value, believe and feel, and manage, if necessary, an adjustment with what the organization proposes they should value or what it is more convenient. Therefore, in the financial system, they must give OC the same relevance as traditional indicators. Finally, it is suggested in future investigations to analyze the OC: (a) current, (b) desired, and (c) the one suggested by the organizations.

\section{References}

Abbasi, H., Sajjadi, S. N., \& Kazemnejad, A. (2013). Validation of the Organizational culture Assessment Instrument (OCAI) based on the Competing Values Framework Model (CVF) within Iranian Sport Organizations (Federations).

Banco Central de Reservas del Perú. (2019). Reporte de Estabilidad Financiera. Recuperado de: http://www.bcrp.gob.pe/docs/Publicaciones/Reporte-Estabilidad-Financiera/2019/noviembre/ref-noviembre-2019.pdf

Barahona Pico, J. A., \& Rodríguez Araujo, D. (2015). La cultura organizacional, un camino para humanizar la implementación del sistema de gestión de calidad - ISO 9001:2008. SIGNOS - Investigación En Sistemas de Gestión, 7(2), 19.

Cameron, K. S., \& Quinn, R. E. (2011). Diagnosing and changing organizational culture: Based on the competing values framework. John Wiley \& Sons.

Felipe, C. M., Roldán, J. L., \& Leal-Rodríguez, A. L. (2017). Impact of Organizational Culture Values on Organizational Agility. Sustainability, 9(12), 2354. https://doi.org/10.3390/su9122354

Fuchs, R. M., \& Torres, C. (2012). Los tipos de cultura y su relación con la rotación organizacional. Journal of Business, 4(1). https://doi.org/10.21678/jb.2012.57

Gómez Romero, J. G. I. (2017). La cultura empresarial y las incapacidades de aprendizaje organizacional en las Mipymes de Durango Capital. Universidad y Empresa, 19(33), 113. https://doi.org/10.12804/revistas.urosario.edu.co/empresa/a.4969

Guillén, I. j., \& Aduna, A. P. (2008). La influencia de la cultura y del estilo de gestión sobre el clima organizacional. Estudio de caso de la mediana empresa en la delegación iztapalapa. Estudios Gerenciales, 24(106), 47-64. https://doi.org/10.1016/s0123-5923(08)70031-7

Gutiérrez Olvera, S., Montañez Moya, G. S., \& Santamaría, C. A. (2017). La responsabilidad social y la cultura organizacional en las empresas familiares. Neumann Business Review, 3(2), 04-22. https://doi.org/10.22451/3002.nbr2017.vol3.2.10009

Hartnell, C. A., Yi Ou, A., \& Kinicki, A. (2011). Organizational culture and organizational effectiveness: a meta-analytic investigation of the competing values framework's theoretical suppositions. Journal of applied psychology, $96(4), 677$.

Hernández, R., Fernández, C. y Baptista, P. (2014). Metodología de la Investigación. México: Me Graw-Hill

Hogan, S. J., \& Coote, L. V. (2014). Organizational culture, innovation, and performance: A test of Schein's model. Journal of Business Research, 67(8), 1609-1621.

Linnenluecke, M. K., \& Griffiths, A. (2010). Corporate sustainability and organizational culture. Journal of World Business, 45(4), 357-366.

MacIntosh, E. W., \& Doherty, A. (2010). The influence of organizational culture on job satisfaction and intention to leave. Sport Management Review, 13(2), 106-117. https://doi.org/10.1016/j.smr.2009.04.006

Máynez-Guaderrama, A. I., Cavazos-Arroyo, J., \& Nuño-De La Parra, J. P. (2012). La influencia de la cultura organizacional y la capacidad de absorción sobre la transferencia de conocimiento tácito intra-organizacional. Estudios Gerenciales, 191211. https://doi.org/10.18046/j.estger.2012.1485

Moonen, P. (2017). The impact of culture on the innovative strength of nations. Journal of Organizational Change Management, 30(7), 1149-1183. https://doi.org/10.1108/jocm-08-2017-0311

Naranjo-Valencia, J. C., Jiménez-Jiménez, D., \& Sanz-Valle, R. (2011). Innovation or imitation? The role of organizational culture. Management decision.

Nguyen, H. N., \& Mohamed, S. (2011). Leadership behaviors, organizational culture and knowledge management practices. Journal of Management Development.

Prajogo, D. I., \& McDermott, C. M. (2011). The relationship between multidimensional organizational culture and performance. International Journal of Operations \& Production Management.

Schein, E. (1983). The role of the founder in creating organizational culture. Organizational dynamics, 12,13-28.

Schneider, B., Ehrhart, M. G., \& Macey, W. H. (2013). Organizational climate and culture. Annual review of psychology, 64, 361-388.

Valle, A. T., Proaño, T. D., \& Cruz, M. E. (2017). Estructura, cultura y cambio organizacional cultura - cambio -forma fuerza. Revista Científica Hermes - FIPEN, 18, 304. https://doi.org/10.21710/rch.v18i0.343

$\mathrm{Yu}, \mathrm{T} .$, \& Wu, N. (2009). A review of study on the competing values framework. International Journal of Business and Management, 4(7), 37-42.

Zheng, W., Yang, B., \& McLean, G. N. (2010). Linking organizational culture, structure, strategy, and organizational effectiveness: Mediating role of knowledge management. Journal of Business Research, 63(7), 763-771. 
(C) 2020 by the authors; licensee Growing Science, Canada. This is an open access article distributed under the terms and conditions of the Creative Commons Attribution (CC-BY) license (http://creativecommons.org/licenses/by/4.0/). 